

\section{VOL. XIII.-1898.}

THE

\section{JOURNAL OF LARYNGOLOGY,}

RHINOLOGY, AND OTOLOGY;

AN ANALYTICAL RECORD OF CURRENT LITERATURE

RELATING TO

\section{THE THROAT, NOSE, AND EAR.}

PUBLISHED MONTHLY.

thanan:

THE REBMAN PUBLISHING COMPANY, LIMITED, i29, Shaftesbury Avenue, Cambridge Circus, W.C.

BNTERED AT STATIONERS HALL. 


\section{THE JOURNAL OF LARYNGOLOGY, RHINOLOGY, AND OTOLOGY.}

Founded in 1887 by MORELL MACKENZIE and NORRIS WOLFENDEN.

EDITORS :

JOHN MACINTYRE, M.B., F.R.S.E., DUNDAS GRANT, M.A., M.D., F.R.C.S.Eng., ARTHUR SANDFORD, M.D., M.Ch.R.U.I.

W. MILligAN, M.D. (Manchester), Sub-Ed.

R. LAKE, F.R.C.S. (London), Managing Sub-Ed.

WITH THE CO-OPERATION OF

Drs. Baron (Bristol), Bettman (Rome), Botey (Barcelona), Price-Brown (Toronto), Cartaz (Paris), Bryson Delavan (New York), Dodo (Chicago), Draispul (St. Petersburg), Grazzi (Florence), Guye (Amsterdam), Hicguet (Brussels), Middlemass Hunt (Liverpool),

Hutchison (Glasgow), Joal (Paris), Karwowski (Warsaw), Kelly (Glasgow), Lacoarret (Toulouse), Lichtwitz (Bordeaux),

Lieven (Aix-la-Chapelle), John N. Mackenzie (Baltimore), Prof. Massei (Naples), Meyjes (Amsterdam), E. Meyer (Berlin), Myles (New York), Holger Mygind (Copenhagen), Porter (St. Louis), Guild (Dundec), Sachs (Hamburg),

StGeorge Reid (London), Rueda (Madrid), Sajous (Philadelphia), Sendziak (Warsaw), Sota (Seville), StClair Thomson (London), WAGGeTt (London), Woods (Dublin), ANd Ziem (Dantzic). 


\section{CONTENTS.}

\section{Original Ertioles-}

The Supratonsillar Fossa and its Affections. By Dr. PAterson ............... 165

Priority of Claim to the Operation on the Antrum of Highmore combining Temporary

Opening in Canine Fossa and Opening in Nose. LAKE $\ldots \ldots \ldots \ldots \ldots \ldots \ldots, 177$

\section{Bocieties' Meetings-}

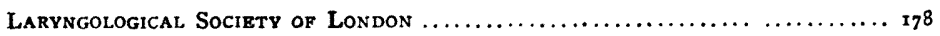

British lakyngological, Rhinological, and Otological Association ...... 185

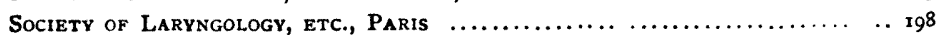

Twelfth International Mrdical Congress, Moscow (concluded) ......... .. 200

\section{Abstracts-}

Diphtheria-The Antitoxin, Tavel

Mouth-Macroglossia, Béault - Resection, Extra-Buccal, Girard-Pharyngitis Sicca, Krebs-Osteomyelitis of Jaw in Infants, Ropke ......................Pages 203 to 205

Nose-Lupus and Roentgen Rays, Albers-Schonberg-Antrum of Highmore, Bergeat Syphilis from Caustic, Burwinkel-Sinusitis, Hajek-Naso-Pharyngeal Polypus, Ischwall - Catarrh of Upper Air Passages, Koppel-Casual Notes, Lanfs - Antitoxin and Ozæna, Lombard - Foreign Body in Nose, Marcuse - Retention Cyst in Frontal Sinus, Martinez Hay Fever, Muller - Empyema of Frontal Sinus, Ropke-Foreign Body in Nose, Semonsohn - Ocular Reflex, Stiel_— Fever and Operations on Superior Air Passages, Winkler

Pages 205 to 209

Larynx-Cancer in Tuberculous Subject, Bar-Cancer, Bergmann-Sudden Death in Children, Berthold - Polypus of Epiglottis, Chiari-Recurrent Paralysis, Chiari - Cyst of Epiglottis, Gaudier-Lupus, Gouguenheim and Guinard-Amyloid Tumour, Martuscelli -Papilloma, Railton -.Tumour, Rosenfeld - Disorders of Speech........Pages 209 to 212

Crsophagus-Pressure Pouch, Butlin ............................. $2 x_{3}$

Thyrold-Thyroid Fever, Bérard - Surgery of Goitre, Doyen .............Page 213

Ear-Extradural Abscess, A uston-Perforation of Membrana Tympani, Bloch-Escape of Cerebro-Spinal Fluid from Ear, Escat-Acoustic Exercises, Gelle-Fatal Otitic Complication, Heiman - Bilateral Ulceration of Auricle, Goldstein-Diplacusis in Rinnés Test, Gradenigo - Paracentesis, Gruber-Labyrinthine Vertigo, Jauhelevitch-Cerebral Abscess, Kalmus - Diabetic Otitis, Korner-Indications for Mastoid Operations, Lake - Bone Con

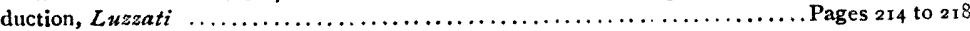

\section{GUIDE TO ADYERTIBEMENTS.}

PAGB

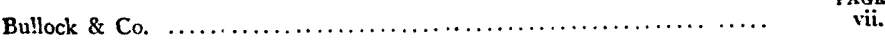

Burroughs, Wellcome \& Co................................... vi.

Central London Throat Hospital $\ldots \ldots \ldots \ldots \ldots \ldots \ldots \ldots \ldots \ldots \ldots \ldots \ldots \ldots \ldots \ldots$ xii.

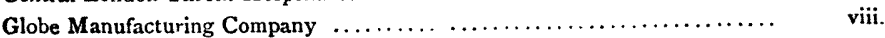

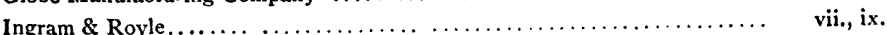

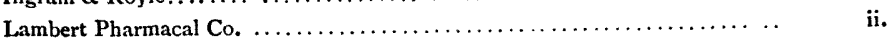

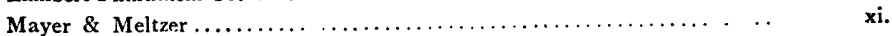

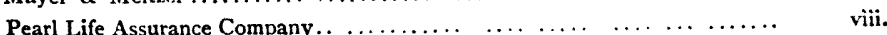

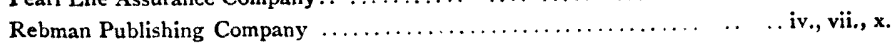

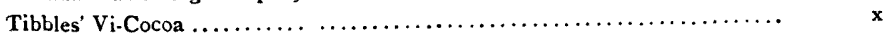

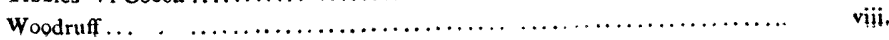




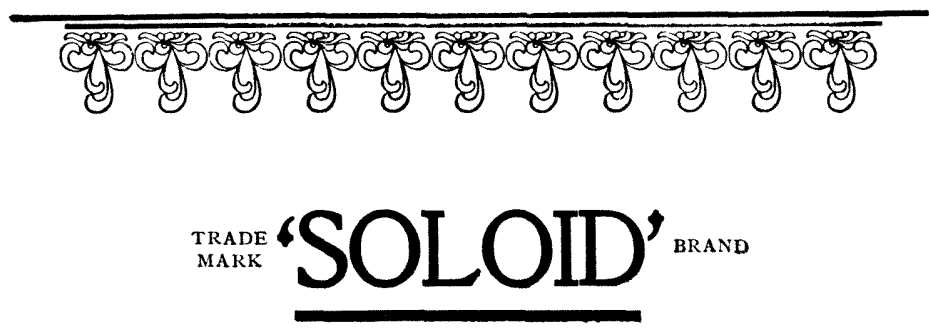

\section{Compressed Medicinal Substances.}

$T^{\prime}$

HE WORD 'SOLOID' is a brand which designates fine products manufactured by BurRoughs WELlCOME AND Co. Under this brand are issued, in accurately divided quantities, substances and combinations of substances which are chiefly used as antiseptics and astringents. They enable

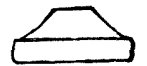
the practitioner to conveniently carry materials for preparing solutions of any desired strength at the moment they are required.

\section{ABRIDGED LIST OF 'SOLOID' PRODUCTS.}

Alum, ro gr.

Alum Compound.

Alumnol, $4 \mathrm{gr}$.

Boric Acia, 6 gr. (scented with Otto of Rose).

Carbolic Acld, gr.

*Chinosol, $8.75 \mathrm{gr}$.

Cocaine Hydrochlorate, $\mathrm{x} / 2, \mathrm{x}$ and $5 \mathrm{gr}$.

Cocaine and Eucaine Hydrochlor., $\mathrm{r} / 2 \mathrm{gr}$. of each.

Eucaine Hydrochloride, I and $5 \mathrm{gr}$.

Fehling's Test, Modified (Cupric Tartrate, Alkaline).

lodic-Hydrarg., I and $8.75 \mathrm{gr}$.

L. G. B.

Mercuric Chloride, $\mathrm{I} .75$ and $8.75 \mathrm{gr}$.
Nasal, Alkaline.

" Alkaline and Antiseptic.

.. 'Eucalyptia' Compound.

". Phenol Compound.

Naso-Pharyngeal.

Ophthalmic, Mercuric Chloride, $\mathrm{r} / \mathrm{r} 000 \mathrm{gr}$

Potassium Permanganate, $5 \mathrm{gr}$.

Silver Nitrate, $\mathrm{I}$ and $5 \mathrm{gr}$.

Sodium Biborate Compound.

Zinc and Tannin Compound.

Zinc Chloride, I and 5 gr.

Zinc Permanganate, $x / 8 \mathrm{gr}$.

Zinc Sulphate, $x$ and $x 0 \mathrm{gr}$.

Zinc Sulphocarbolate, 2 and ro gr.

* By special arrangement with the Licensee.

\section{Burroughs Wellcome and Co., LONDON and SYDNEY.}

